\title{
Peningkatan Keterampilan Berbicara Melalui Metode Pembelajaran Berbasis Masalah Siswa Sekolah Dasar Manokwari Papua Barat
}

\author{
Densemina Yunita Wabdaron ${ }^{1 \bowtie} \&$ Yansen Alberth Reba ${ }^{2}$ \\ ${ }^{1}$ Sekolah Tinggi Keguruan dan Ilmu Pendidikan (STKIP) Hermon Timika \\ ${ }^{2}$ FKIP, Universitas Cenderawasih. Indonesia \\ e-mail: densemina.yunita@gmail.com
}

\begin{abstract}
Abstrak
Penelitian ini bertujuan untuk meningkatkan keterampilan berbicara kelas V SDN 69 Amban Manokwari Papua Barat. Penelitian ini dilakukan melalui Penelitian Tindakan Kelas (PTK) menggunakan model Kemmis dan Mc. Taggart, penelitian tersebut dilakukan dalam dua siklus. Masing-masing siklus terdiri dari tahap perencanaan, implementasi tindakan pengamatan dan refleksi tindakan. Subjek penelitian peserta didik adalah siswa kelas V SD. Proses pengumpulan data melalui tes keterampilan berbicara dan non tes berupa hasil observasi, pelaksanaan metode pembelajaran berbasis masalah dengan menggunakan lembar observasi dan aktivitas guru dan siswa catatan lapangan dan dokumentasi. Hasil penelitian menunjukkan adanya peningkatan keterampilan berbicara. Hal ini dibuktikan siswa yang tuntas pada tindakan siklus I yaitu $48 \%$ dan pada siklus II meningkat menjadi $92 \%$. Adapun hasil pengamatan siklus I pada aktivitas guru mencapai $71 \%$ dan aktivitas siswa mencapai $62,5 \%$. Pada siklus II aktivitas guru mengalami peningkatan $89 \%$ dan aktivitas siswa juga mencapai $89 \%$. Dengan demikian penggunaan metode pembelajaran berbasis masalah dapat meningkatkan keterampilan berbicara siswa kelas V SD Negeri 69 Amban Manokwari Papua.
\end{abstract}

Kata Kunci: Keterampilan Berbicara; Metode Pembelajaran Berbasis Masalah; Penelitian Tindakan.

\begin{abstract}
This action research aims to improve the students' speaking skill of grade V SDN 69 Amban Manokwari, Papua, through problem-based learning method. This research used Kemmis and Mc Taggart Model. The study was conducted in two cycles. Each cycle consists of the planning stage, the implementation of the observation, and the reflection of the action. The subjects of the study were the students of grade V SDN 69 Amban Manokwari, Papua. The data were collected through speaking test and observation. The problem based learning method was applied by using observation sheet, teacher's activity, students' field record and documentation. The result showed that the students' speaking skill improves. It can be seen from the students' completion in the first cycle reached $48 \%$ and in the second cycle it increased to $92 \%$. The result of observation cycle I on teacher's activity reached $71 \%$ and students' activity reached $62.5 \%$. In the second cycle of teacher's activity increased $89 \%$ and students' activity also reached $89 \%$. Thus the use of problem-based learning method can improve the students' speaking skill of grade V SDN 69 Amban Manokwari, Papua.
\end{abstract}

Keywords: Speaking skill; Problem Based Learning; Action Research 


\section{PENDAHULUAN}

Pendidikan memiliki pengaruh yang sangat dinamis dalam kehidupan manusia sejak manusia mulai terbentuk dalam kandungan ibu sampai lahir kedunia, bertumbuh dan berkembang, baik masa kini maupun masa depan. Selain itu pendidikan merupakan sebuah sarana dimana manusia dapat mengembangkan segala potensi yang ada dalam dirinya secara optimal (Kurniawan, 2015). Potensi individu itu sendiri meliputi aspek fisik, intelektual, psikis, karakterisitik, keterampilan maupun lingkungan sosial budaya dimana manusia itu hidup.

Keterampilan berbahasa mencakup empat aspek, (1) Keterampilan menyimak, (2) Keterampilan berbicara, (3) Keterampilan membaca, dan (4) keterampilan menulis (Ripai, 2012). Setiap keterampilan mempunyai hubungan erat dengan keterampilan-keterampilan lainnya. Keterampilan-keterampilan tersebut hanya dapat dikuasai dengan jalan praktik dan latihan yang berkelanjutan (Rezeki, Syahrial \& Surya, 2019).

Berbicara merupakan salah satu aspek keterampilan berbahasa yang bersifat produktif, artinya suatu kemampuan yang seseorang menyampaikan gagasan, pikiran atau perasaan yang ada dalam pikiran pembicara (Wiyanti, 2015). Dengan demikian berbicara berarti mengemukakan ide atau pesan lisan secara aktif melalui lambanglambang bunyi agar terjadi kegiatan komunikasi antara tutur dan mitra tutur (Setyawati, 2012). Berbicara adalah suatu keterampilan berbahasa yang berkembang pada kehidupan anak, yang didahului oleh keterampilan menyimak dan pada masa tersebutlah keterampilan berbicara atau berujar dipelajari (Sukmawati \& Purbaningrum, 2015). Pada kehidupan sehari-hari siswa selalu melakukan kegiatan berbicara namun pada kenyataannya pembelajaran berbicara di sekolah belum dikatakan maksimal di kelas V Sekolah Dasar Negeri 69 Amban Manokwari.

Permasalahan dalam berbicara, menurut hasil survei penulis bahwa pada umumnya siswa mengalami hambatan berbicara ketika diberi tugas oleh guru untuk menyampaikan pesan di depan kelas. Siswa kesulitan mengungkapkan ide pendapat, gagasan, kurang menguasai materi yang diberikan guru (Artha, Bharata \& Caswita, 2014). Selain itu siswa tidak membiasakan diri untuk berani berbicara, merasa takut salah, kurangnya rasa percaya diri, dan kurang mampu mengembangkan keterampilan bernalar dalam berbicara (Ayu, Kurniati \& Seran, 2015). Pelafalan dalam berbicara belum jelas, bahkan kalimatkalimat yang diucapkan ketika berbicara sebagian kalimat masih menggunakan bahasa daerah (Saputri, Nur Amalia \& Teach, 2018). Struktur kalimat masih belum lengkap bahkan ketika berbicara siswa sepertinya kehabisan kata-kata membuat siswa menjadi bingung di depan kelas dan menjadi tidak percaya diri (Pusparatri, 2012).

Kesulitan-kesulitan tersebut membuat siswa tidak mampu mengungkapkan pikiran dan gagasan yang baik, sehingga siswa menjadi enggan untuk mengungkapkan ideide kreatifnya (Tristiantari, Marhaeni \& Koyan, 2013). Berdasarkan pengalaman survei di lapangan juga bahwa guru kurang kreatif menyampaikan materi, guru lebih suka berceramah, memberikan tugas mandiri seperti pekerjaan rumah. Hal terssebut mengakibatkan siswa terbiasa dengan bantuan orang lain di luar sekolah seperti orang tua, saudara, teman atau siapa saja (Chairani, 2014). Ketika siswa diperhadapkan dengan kegiatan presentase untuk mempertanggungjawabkan hasil kerja siswa terlihat gugup dan ketakutan (Riani \& Rozali, 2014).

Berbicara adalah keterampilan menyampaikan pesan melalui bahasa lisan atau berbicara adalah kemampuan mengucapkan bunyi-bunyi artikulasi atau kata-kata untuk mengekspresikan, menyatakan, serta menyampaikan pikiran, gagasan dan perasaan (Yunus, 2015). Berbicara lebih dari sekedar pengucapan bunyi-bunyi atau kata-kata karena berbicara adalah sarana untuk mengkomunikasikan gagasan-gagasan yang disusun serta 
dikembangkan sesuai dengan kebutuhan pendengar (Istiqomah, 2015). Berbicara pada dasarnya kemampuan seseorang untuk mengeluarkan ide, gagasan, ataupun pikirannya kepada orang lain dengan menggunakan media bahasa lisan (Lubis, 2012).

Faktor lain dari rendahnya keterampilan berbicara, yaitu berhubungan dengan kajian fonetik. Ketidaklancaran berbicara merujuk pada kegagalan atau ketidakmampuan seseorang untuk berkomunikasi dengan menggunakan bahasa lisan dengan lancar dan berkesan. Beberapa kasus ini sering dikaitkan dengan ketidakmampuan belajar individu yang bersangkutan.

"Language disabilities commonly associated with learning disabilities swich can be predicted on the basic of the youngster's rate of the linguistic rule. In the area of language, learning disabled children may have problems forming verbal abstractions and performing the logical expressed in language. Their oral problems may lead to deficits in perceiving and interpreting as well as informulating and producing," (Mulislich, 2009).

Ketidakmampuan belajar bahasa dapat diprediksi berdasarkan standar aturan linguistik. Masalah dalam keterampilan berbicara, salah menafsirkan informasi dan memproduksi bahasa kembali. Mencermati latar belakang di atas, peneliti memprediksi bahwa melalui metode pembelajaran berbasis masalah (PBM), keterampilan siswa dalam berbicara akan meningkat.

Metode Pemecahan Masalah adalah cara penyajian bahan pembelajaran dengan menyajikan masalah sebagai titik tolak pembahasan untuk dianalisis dan disintesin dalam usaha mencari pemecahan atau jawabannya oleh siswa (Sudirman, 1991). Metode Pemecahan Masalah adalah cara penyajian bahan pembelajaran dengan menyajikan masalah sebagai titik tolak pembahasan untuk dianalisis dan disintesin dalam usaha mencari pemecahan atau jawabannya oleh siswa ( Zenal \& Anung, 2016). Metode pemecahan masalah memusatkan pada masalah kehidupan yang bermakna bagi peserta didik (Al-idrus, Hikmawati \& Wahyudi, 2015). Peran guru pada metode pembelajaran berbasis masalah adalah menyajikan masalah, mengajukan pertanyaan dan memfasilitasi penyelidikan (Maryati, 2018).

Metode Pembelajaran Berbasis Masalah (Problem Based Learning) merupakan langkah-langkah pembelajaran yang menitik beratkan masalah sebagai kekuatan dalam meningkatkan cara berpikir tingkat tinggi menemukan dan memecahkan masalah sebagai penguatan konsep pengetahuan peseta didik dengan melibatkan lingkungan kehidupan atau pengalaman sehari-hari (Lidinillah, 2013). Pembelajaran berbasis masalah terdiri dari: (1) Orientasi siswa pada masalah, (2) Menegosiasikan siswa dalam belajar, (3) Membimbing penyelidikan individual/kelompok, Mengembangkan dan menyajikan hasil karya, (5) Menganalisis dan mengevaluasi pemecahan masalah (Purwatiningsi, 2013).

Dengan diterapkannya metode pembelajaran berbasis masalah dalam pembelajaran keterampilan berbicara diharapkan mampu menstimulus siswa agar mengikuti pembelajaran dengan baik, siswa dapat melaksanakan kegiatan menyimak aktif reseptif, serta dapat memotivasi siswa meningkatkan keterampilan berbicara.

\section{METODE PENELITIAN}

Metode penelitian yang digunakan dalam penelitian ini yaitu Action Research. Penelitian tindakan yang digunakan dalam penelitian ini adalah dengan menggunakan model Kemmis dan Mc. Taggart yang terdiri dari tahap perencanaan tindakan (planning), tahap pelaksanaan tindakan (acting), tahap observasi pelaksanaan tindakan (observing), tahap refleksi tindakan (reflecting). Penelitian ini sesuai dengan prosedur penelitian tindakan. Penelitian tindakan ini dilakukan sebagai upaya untuk perbaikan keterampilan berbicaramelalui metode pembelajaran berbasis masalah $(\mathrm{PBM})$ pada siswa kelas V SD Negeri SDN 69 Amban Manowari Papua 
Pada penelitian tindakan ini dilaksanakan dalam beberapa siklus pada pada tema 4 "Sehat Itu Penting" sub tema 1 "Pentingnya Kesehatan Diri". Dengan kompetensi dasar 3.2. Siklus I dilaksanakan dalam enam kali pertemuan, satu pertemuan dengan alokasi waktu 2x45 menit. Kegiatan tersebut dapat dideskripsikan sebagai berikut.

\section{Perencanaan}

Pada tahap perencanaan, peneliti melakukan perundingan dengan kepala sekolah dan guru kelas V SDN 69 Amban Manowari Papua untuk memberitahukan maksud serta tujuan kegiatan penelitian tindakan kelas ini. Guru dan peneliti kemudian berdiskusi mengenai perencanaan pelaksanaan pembelajaran sesuai dengan fokus penelitian, yaitu penggunaan metode pembelajaran berbasis masalah dalam meningkatkan keterampilan berbicara siswa di kelas V SD.

Berikut tahapan perencanaan tindakan yang dilakukan oleh peneliti yaitu: menganalisis kurikulum untuk mengetahui kompetensi dasar yang akan digunakan dalam pelaksanaan pembelajaran menyimak melalui media muliliterasi, menyiapkan materi pembelajaran yang akan disampaikan, pada tema 4 "Sehat Itu Penting" sub tema 1 "Pentingnya Kesehatan Diri". Dengan kompetensi dasar 3.2. Menguraikan isi teks penjelasan tentang proses daur air, rangkaian listrik, sifat magnet, anggota tubuh (manusia, hewan, tumbuhan) dan fungsinya, serta sistem pernapasan dengan bantuan guru dan teman dalam bahasa Indonesia lisan dan tulis dengan memilih dan memilah kosa kata baku mengidentifikasi pentingnya manfaat air bagi makhluk hidup (manusia hewn dan tumbuhan dari teks).

4.2. Mengamati, mengolah, dan menyajikan teks proses daur air tentang makanan dan rantai makanan, kesehatan manusia, keseimbangan ekosistem, serta alam dan pengaruh kegiatan manusia secara mandiri dalam bahasa Indonesia lisan dan tulis dengan memilih dan memilah kosakata baku.

\section{Melaksanakan Tindakan}

Pada tahap ini, peneliti melaksanan tindakan berdasarkan rencana tindakan yang Merancang upaya - upaya kegiatan belajar yang maksimal sehingga mampumeningkatkan keterampilan kognitif, afektif dan psikomotorik, terutama pada keterampilan berbicara siswa Kelas V. Pelaksanaan tindakan ini dilaksanan sesuai dengan langkah-langkah penyajian data yang meliputi mengatur pola duduk siswa, menetapkan prosedur dalam pelaksanaan pembelajaran, menyajikan teks yang akan digunakan dalam pembelajaran berbicara sesuai dengan tema dan subtema, melakukan evaluasi terhadap tindakan.

\section{Observasi}

Observasi dilaksanakan bersamaan dengan implementasi tindakan sesuai pembelajaran berbicara menggunakan metode pembelajaran berbasis masalah. Informasi yang akan dikumpulkan adalah data-data dari proses pembelajaran berupa kinerja guru, aktivitas siswa dan situasi dan kondisi dalam pembelajaran di kelas.

Observasi kinerja guru dalam proses belajar mengajar di kelas dapat diamati dengan menggunakan lembar observasi guru yang dilakukan oleh rekan sejawat sehingga pembelajaran untuk meningkatkan keterampilan berbicara dapat terekam secara optimal.

Dalam setiap tindakan, peneliti memantau dan mencatat kegiatan-kegiatan penting yang terjadi selama proses pembelajaran dengan menggunakan pedoman observasi, catatan lapangan dan dokumentasi.

\section{Refleksi}

Kegiatan refleksi akan dilaksanakan ketika peneliti selesai melaksanakan tindakan. Refleksi berupa diskusi balikan dengan kolaborator, analisis keterampilan menyimak, mencatat segala temuan-temuan selama tindakan baik yang dianggap kelebihan dan kekurangan.

Refleksi dilaksanakan dari setiap data yang diperoleh dari hasil tindakan terhadap siswa kelas IV Sekolah Dasar Mandalaherang III. Jika tindakan belum berhasil mengenai target penelitian maka pada siklus berikutnya dirumuskan kembali 
rencana tindakan dalam skenario pembelajaran yang telah direvisi untuk dilaksanakan pada siklus penelitian berikutnya untuk mencapai target penelitian.

Minimal sampai 80\% dari jumlah siswa yang hasil keterampilan berbicara mencapai nilai 70. Kriteria keberhasilan ini sesuai dengan KKM di kelas V SDN 69 Amban Manowari Papua.

Dalam penelitian tindakan akan berkaitan erat dengan data dan sumber data. Data dalam penelitian tindakan ini meliputi, data kuantitatif dan data kualitatif. Data kuantitatif yaitu nilai hasil kinerja keterampilan berbicara pada mata pelajaran bahasa Indonesia yang diperoleh dengan menggunakan tes lisan. Data kualitatif yaitu proses pembelajaran terdiri dari lembar pengamatan pendidik selama proses belajar mengajar dengan menggunakan metode PBM.

Sumber data dalam penelitian ini adalah penelitian keterampilan menyimak di SDN 69 Amban Manowari Papua., tahun pelajaran 2016/2017 yang berjumlah 25 siswa. Adapun observer terlibat dalam penelitian ini adalah guru kelas $\mathrm{V}$ yang dapat bekerja sama dalam pengamatan kinerja guru serta memberikan masukan berupa kritik dan saran yang membangun dalam penelitian.

\section{HASIL DAN PEMBAHASAN}

Kriteria keberhasilan tindakan atau keberhasilan pencapaian tujuan penelitian dapat dilihat dari keberhasilan guru dan siswa melaksanakan pembelajaran keterampilan berbicara melalui metode PMB. Siswa harus mendapatkan skors berbicara maksimal 70 atau melampaui nilai 70 karena kriteria ketuntasan minimal keterampilan menyimak adalah 70. Jika hasil pembelajaran sudah mencapai hasil yang ditargetkan maka penelitian tindakan tidak akan dilanjutkan. Adapun gambaran umum hasil pembelajaran keterampilan berbicara siswa.

Evaluasi yang dilaksanakan pada akhir pertemuan untuk mengukur pemahaman dan keterampilan siswa dalam berbicara. Evaluasi yang dilaksanakan pada aspek psikomotor. Adapun hasil keterampilan berbicara siswa akan disajikan pada tabel berikut.

Tabel 1. Hasil Ketuntasan Keterampilan Berbicara Siklus I

\begin{tabular}{ccc}
\hline $\begin{array}{c}\text { Hasil } \\
\text { Keterampilan } \\
\text { Berbicara }\end{array}$ & $\begin{array}{c}\text { Jumlah } \\
\text { Siswa }\end{array}$ & Persentase \\
\hline Tuntas & 12 Siswa & $48 \%$ \\
Belum Tuntas & 13 Siswa & $52 \%$ \\
Jumlah & 25 Siswa & $100 \%$ \\
\hline
\end{tabular}

Berdasarkan tabel di atas siswa yang tuntas berjumlah 12 siswa (48\%) dan yang tidak tuntas berjumlah 13siswa (52\%). Hal tersebut menunjukkan bahwa keterampilan berbicara siswa belum mencapai target yang telah ditentukan.

Terdapat dua aspek dalam penilaian dalam mengukur keterampilan berbicara yakni aspek kebahasaan dan aspek non kebahasaan.Setelah dilakukannya tes didaptilah bahwa dari 25 siswa yang mengikuti tes, tidak ada siswa $(0 \%)$ yang meraih nilai kisaran 85-100 (peringkat A), dua belas siswa (48\%) yang meraih nilai kisaran 70-84 (peringkat B), delapan siswa $(32 \%)$ yang meraih niai kisaran 5569(peringakat C) dan lima siswa yang meraih nilai kisaran 55-69 (peringkat C), dan tidak ada siswa (20\%) yang meraih nilai kurang dari 55 (peringkat D). Apabila dirata-ratakan maka keseluruhan siswa mendapat nilai ratarata sebesar $63.8 \%$

Hasil penelitian untuk setiap aspek peniaian psikomotorik menunjukkan bahwa aspek artikulasi meraih nilaikeberhasilan sebesar $61 \%$ (cukup), aspek kosa kata meraih nilai keberhasilan sebesar 57\%(kurang) aspek struktur kalimat meraih nilai keberhasilan sebesar $61 \%$ (cukup), aspek isi pembicaraan meraih nilai keberhasilan sebesar $50 \%$ (kurang), aspek keberanian meraih nilai keberhasilan 50\% (kurang), aspek kelancaran meraih nilai keberhasilan 63\% (cukup) dan aspek kenyaringan suara meraih nilai keberhasilan 50\% (baik). Hasil tesebut menggambarkan bahwa masih rendahnya pencapaian yang didapatkan oleh siswa pada ranah psikomotorik. Untuk 
mendapatkan gambaran secara visual mengenai hasil keterampilan berbicara, dapat disajikan dalam bentuk diagram batang sebagai berikut.

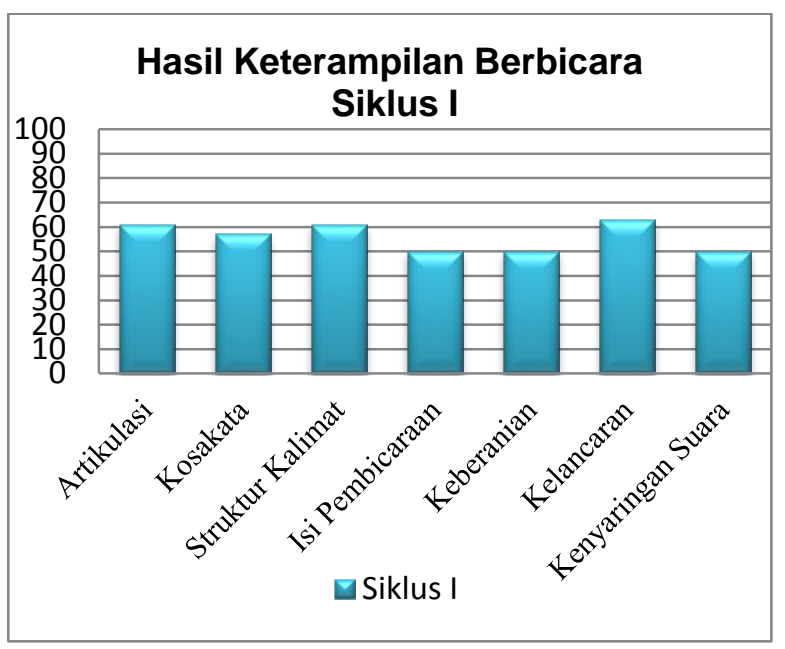

Gambar 1. Diagram Batang Hasil Keterampilan Berbicara Siklus

Hasil keterampilan berbicara siswa belum memenuhi target yang diharapkan oleh karena itu perlu adanya tindakan selanjutnya pada siklus II. Kegiatan pembelajaran yang dilaksanakan harus lebih inovatif, menarik perhatian siswa dan kreatif agar hasil keterampilan menyimak melalui metode pembelajaran berbasis masalah lebih meningkat.

Tes keterampilan berbicara pada siklus II dilaksanakan pada akhir pertemuan untuk mengukur pemahaman dan keterampilan siswa dalam berbicara. Adapun hasil keterampilan menyimak siswa digambarkan sebagai berikut.

Tabel 2. Hasil Ketuntasan Keterampilan Berbicara Siklus II

\begin{tabular}{clc}
\hline $\begin{array}{c}\text { Hasil } \\
\begin{array}{c}\text { Keterampilan } \\
\text { Menyimak }\end{array}\end{array}$ & $\begin{array}{c}\text { Jumlah } \\
\text { Siswa }\end{array}$ & Persentase \\
\hline Tuntas & 23 Siswa & $92 \%$ \\
$\begin{array}{c}\text { Belum Tuntas } \\
\text { Jumlah }\end{array}$ & 2 Siswa & $8 \%$ \\
& 25iswa & $100 \%$ \\
\hline
\end{tabular}

Berdasarkan data pada tabel di atas, siswa yang tuntas berjumlah 23 siswa dengan persentase (92\%) sedangkan siswa yang tidak tuntas berjumlah dua siswa dengan persentase $8 \%$. Hasil tersebut telah mencapai target yang telah ditentukan.

Setelah dilakukannya tes didapatilah bahwa dari 25 siswa yang mengikuti tes terdapat sepuluh siswa (40\%) yang meraih nilai kisaran 85-100 (peringkat A), tiga belas siswa (52\%) yang meraih nilai kisaran 70-84 (peringkat B), dua siswa (8\%) yang meraih nilai kisaran 55-69 (peringkat $C$ ) dan tidak ada siswa (0\%) meraih nilai kurang dari 55 (peringkat D). Apabila dirata-ratakan maka keseluruhan siswa mendapat nilai rata-rata sebesar 81.6.

Hasil penelitian untuk setiap aspek peniaian psikomotorik menunjukan bahwa aspek artikulasi meraih nilai keberhasilan sebesar 67\% (cukup), aspek kosa kata meraih nilai keberhasila sebesar 70\% (baik), aspek struktur kalimat meraih nilai keberhasilan sebesar 68\% (cukup), aspek isi pembicaraan meraih nilai keberhasilan sebesar $68 \%$ (cukup), aspek keberanian meraih nilai keberhasilan 70\% (baik), aspek kelancaran meraih nilai keberhasilan $83 \%$ (baik) dan aspek kenyaringan suara meraih nilai keberhasilan 86\% (Amat baik). Adapun gambaran secara visual sebagai berikut.

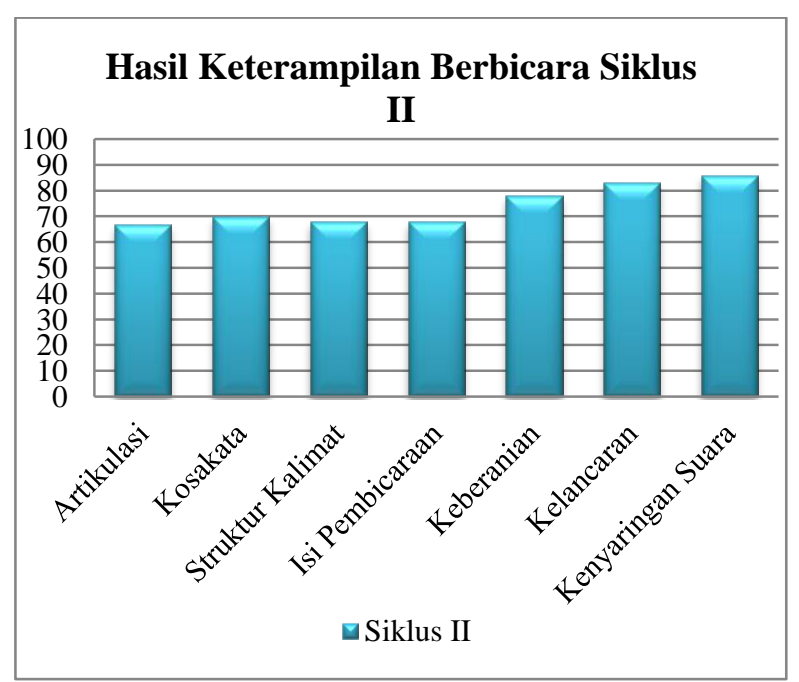

Gambar 2. Hasil Keterampilan Berbicara Siklus II

Berdasarkan diagram diatas di atas hasil keterampilan berbicara siswa sudah memenuhi target yang diharapkan, maka penelitian dalam upaya meningkatkan 
keterampilan berbicara melalui metode pembelajaran berbasis masalah pada SD N 69 Amban Manokwari dihentikan pada tindakan Siklus II.

Analisis data dilakukan dengan menggunakan statistik sederhana yaitu dengan menggunakan analisis deskriptif. Analisis deskriptif adalah model analisis dengan cara membandingkan rata-rata persentasenya. Adapun yang akan disajikan dalam pembahasan mengenai hasil observasi terhadap aktivitas guru, siswa dan hasil tes keterampilan berbicara .

Dari hasil pengisian lembar aktivitas guru dan siswa yang dilakukan pada saat kegiatan pembelajaran, diperoleh data sebagai berikut.

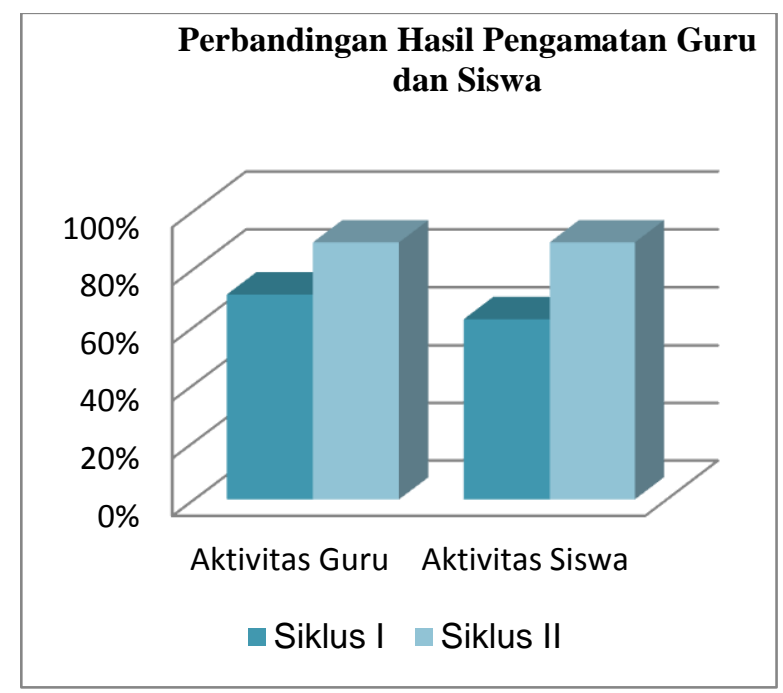

Gambar 3. Perbandingan Hasil Pengamatan Guru dan Siswa

Dari diagram di atas, dapat diketahui bahwa kinerja guru dan siswa dalam melaksanakan pembelajaran keterampilan berbicara melalui metode PBM. Secara garis besar perbandingan antara kegiatan yang dilakukan oleh guru dan siswa mengalami peningkatan yang signifikan yang berdampak positif terhadap hasil keterampilan berbicara. setelah menerapkan metode PBM, terdapat peningkatan dari pra siklus, siklus I dan siklus II.

Hasil tes keterampilan berbicara mengalami peningkatan. Peningkatan keterampilan berbicara dipengaruhi oleh beberapa faktor, diantaranya saat kegiatan pembelajaran pada siklus II. Siswa lebih mudah mengikuti kegiatan berbicara dibandingkan pada pra siklus dan siklus I. Selain itu, siswa sudah terlibat aktif dalam kegiatan pembelajaran. Siswa juga sudah berani bertanya dan memberikan pendapat kepada temannnya.

Hasil tersebut menunjukkan bahwa perbaikan pembelajaran khususnya peningkatan keterampilan berbicara degan metode PBM dapat tercapai. Hal ini terlihat adanya peningkatan hasil belajar dari sebelum dilakukannya pra siklus sampai dengan siklus II.

Dari hasil kegiatan pembelajaran pada siklus II terlihat jelas bahwa proses pembelajaran sudah cukup optimal, guru dan siswa bersama-sama terlibat dalam aktivitas pembelajaran. Hal ini bisa terlihat dari hasil penilaian dan pengamatan pada siklus II adanya kenaikan penyerapan siswa terhadap materi yang diajarkan secara signifikan. Hal ini dimungkinkan guru dalam kegiatan pembelajarannya melakukan perubahanperubahan dan memperbaiki kekurangankekurangan yang dialami pada siklus I.

\section{KESIMPULAN}

Berdasarkan hasil penelitian maka ditarik kesimpulan bahwa dalam meningkatkan keterampilan berbicara metode pembelajaran berbasis masalah merupkan salah satu metode yang sangat tepat di gunakan dalam proses belajar, terbukti pada proses belajar dengan tema 4 "Sehat itu Penting dan sub tema 1 "pentingnya menjaga kesehatan diri dan lingkungan melalu tes keterampilan berbicara yang dilakukan pada siklus I dan siklus II.

Keterampilan berbicara siswa pada anak kelas V SDN 69 Amban Kabupaten Manokwari Papua Barat masih rendah pada siklus I hal ini di buktikan melalui tes berbiara dengan menggunakan instrument penlaian yaitu rubrik penilaian keterampilan berbicara menunjukan bahwa siswa meraih nilai rata-rata $63,8 \mathrm{~S}$ dengan tingkat keberhasilan siswa 48\%. Angka ini sangat jauh dari Kriteria Ketuntasan Minimal (KKM) yakni 70. 
Melihat pada hasil siklus I yang masih rendah maka dalam upaya meningkatkan keterampilan berbicara, maka penerapan metode pembelajaran berbasis masalah dilakukan berbagai upaya seperti memberikan stimulus lebih kepada siswa dengan cara memancing siswa lebih banyak menanya, mengandakan media pembelajaran yang lebih variatif dengan untuk mendapatkan respons dari siswa.

Pada proses siklus II terlihat siswa menjadi lebih baik keterampilan berbicaranya setelah dilakukan beberapa tindakan seperti menambahmedia pembelajaranyang bervariatif, pembimbingan kepada siswa harus lebih intens.Siswa perlu banyak di latih untuk berbicara secara sistematis dalam memecahkan permasalahan yang di hadapi melalui kerja kelompok, melatihsiswamenggorganisir,mengidentifikas i, mencari, menemukan memberikan solusi dari kasus yang sedang pecahkan, siswa juga terlihat aktif dalam berkolaborasi bersama teman sejawat. Pada siklus II terlihat adanya peningkatan dengan bukti bahwa pada tes keterampilan berbicara ternyata niai rata-rata siswa mencapai 81,6 atau berkisar 92\% berhasil.

Dengan demikian dapat disimpulkan bahwa dalam upaya meningkatkan keterampilan berbicara siswa kelas V SD metoe pembelajaran Berbasis masalah merupakan salah satu metode yang mampu meningkatkan keterampilanberbicara, siswa terlihat lebih aktif dalam memecahkan masalah sebagai topik utama dalam metode dimaksud, siswa telihat lebih berani mengungkapkan ide-ide, gagasan-gagasan, serta mampu menemukan solusi sebagai hasil dari proses belajar dimaksud.

\section{UCAPAN TERIMAKASIH}

Ucapan terimakasih yang sedalamdalamnya kepada semua pihak yang telah membantu demi suksesnya penelitian tindakan ini antara lain,"Lembaga Pengelolah Dana Pendidikan (LPDP) Republik Indonesia" sebagai Pendonor utama suksesnya Action Research penulis, para nara sumber dan Kepala Sekolah SD
Negeri 69 Amban Manokwari Papua serta semua pihak yang terkait. Semoga Tuhan yang Maha Kuasa memberkati bapak/ibu sekalian.

\section{DAFTAR RUJUKAN}

Al-idrus, S. Q. M. J., Hikmawati, H., \& Wahyudi, W. (2015). Pengaruh model pembelajaran berbasis masalah berbantuan video kartun terhadap hasil belajar fisika siswa kelas xi sman 1 sikur tahun ajaran 2014/2015. Jurnal Pijar MIPA, 10(1).

Arifin, Zaenal \& Haryono (2016). Metode Pengajaran Bahasa dan Sastra (Tangerang: Pustaka Mandiri Penerbit buku super).

Artha, R. A., Bharata, H., \& Caswita, C. (2014). Penerapan Model Pembelajaran Berbasis Masalah untuk Meningkatkan Kemampuan Representasi Matematis Siswa. Jurnal Pendidikan Matematika Unila, 2(4).

Ayu, L. C., Kurniati, A., \& Seran, E. Y. (2015). Studi Survei Kemampuan Berbicara Siswa pada Pembelajaran Bahasa Indonesia di Kelas V: Jurnal Penelitian Pendidikan Dasar, 1(1), 44-58.

Chairani, M. (2014). Komunikasi interpersonal guru dan orang tua dalam mencegah kenakalan remaja pada siswa (studi deskriptif pada siswa kelas XI SMA Kolombo Sleman). Jurnal Ilmu Komunikasi, 7 (2).

Istiqomah, U. (2015). Upaya Meningkatkan Kemampuan Berbicara Melalui Penggunaan Media Flash Card Pada Anak Kelompok A TK Pertiwi I Dukuh Banyudono Boyolali Tahun Pelajaran 2014 / 2015 ( Doctoral dissertation, Universitas Muhammadiyah Surakarta ). 
Kurniawan, M. I. (2015). Tri Pusat Pendidikan Sebagai Sarana Pendidikan Karakter Anak Sekolah Dasar. PEDAGOGIA: Jurnal Pendidikan, 4(1), 41-49.

Lidinillah, D. A. M. (2013). Pembelajaran berbasis masalah (problem based learning). Jurnal Pendidikan Inovatif, 5(1), 17.

Lubis, C.(2012). Meningkatkan Kemampuan Berbicara Siswa Pada Pelajaran Bahasa Indonesia Dengan Menggunakan Metode Bermain Peran Bagi Siswa Kelas V SD Swasta Cendekia T. A 2011/2012 (Doctoral dissertation, UNIMED).

Maryati, I. (2018). Penerapan Model Pembelajaran Berbasis Masalah pada Materi Pola Bilangan di Kelas VII Sekolah Menengah Pertama. Mosharafa: Jurnal Pendidikan Matematika, 7 (1), 63 74.

Mulislich, Masnur (2009). Fonologi Bahasa Indonesia Tinjauan Deskriptif Bunyi Bahasa Indonesia, (Jakarta: Bumi Aksara,)

Purwatiningsi, S. (2013). Penerapan metode penemuan terbimbing untuk meningkatkan hasil belajar siswa pada materi luas permukaan dan volume balok. Jurnal Elektronik Pendidikan Matematika Tadulako, 1 (1).

Pusparatri, R. K. D. (2012). Strategi pembelajaran berbasis masalah untuk meningkatkan kemampuan berpikir kritis siswa. Jurnal Ilmiah Guru Caraka Olah Pikir Edukatif, 16 (2).

Rezeki, N., Syahrial, S., \& Surya, Y. F. (2019). Peningkatan Keterampilan Berbicara Dengan Menggunakan Model Kooperatif Think Pair Share. Jurnal Pendidikan Tambusai, 3 (5), 946-954.
Riani, W. S., \& Rozali, Y. A. (2014). Hubungan antara self efficacy dan kecemasan saat presentasi pada mahasiswa univeristas esa unggul. Jurnal Psikologi Esa Unggul, 12(01).

Ripai, A. (2012). Pengembangan Teknik Berpikir Berpasangan Berbagi Pembelajaran Menulis Teks Drama yang Bermuatan Nilai-Nilai Pendidikan Karakter pada Mahasiswa Pendidikan Bahasa dan Sastra Indonesia. Seloka: Jurnal Pendidikan Bahasa dan Sastra Indonesia, 1(2).

Saputri, R. W., Nur Amalia, S. S., \& Teach, M. (2018). Analisis Keterampilan Berbicara Siswa Kelas Tinggi Pada Pembelajaran Bahasa Indonesia Di SD Negeri 2 Selo (Doctoral dissertation, Universitas Muhammadiyah Surakarta).

Setyawati, R. (2012) . Peningkatan Keterampilan Berbicara Dengan Menggunakan Metode Role Playing Pada Mata Pelajaran Bahasa Indonesia Siswa Kelas V Di SD Negeri 01 Malanggaten Kebakkramat Karanganyar Tahun Pelajaran 2011 / 2012 ( Doctoral dissertation, Universitas Muhammadiyah Surakarta).

Sudirman N \& A. Tabrani Rusyan, Zainal Arifin, Toto Fathon (1991). Ilmu Pendidikan. (Bandung: PT Remaja Rosdakarya,).

Sukmawati, D., \& Purbaningrum, E (2015). Pengaruh Model Pembelajaran Ekspositori Terhadap Kemampuan Berbicara Anak. Paud Teratai, 4(2).

Tarigan, Henry Guntur (2015). Berbicara Sebagai Suatu Keterampilan Berbahasa (Bandung: Angkasa Bandung).

Tristiantari, N. K. D., Marhaeni, A. A. I. N., \& Koyan, I. W. (2013). Pengaruh 
Implementasi Model Pembelajaran Kooperatif Tipe Tps Terhadap Kemampuan Berbicara Dan Keterampilan Berpikir Kreatif Pada Siswa Kelas V SD Negeri Gugus III Kecamatan Seririt. Jurnal Pendidikan Dasar Ganesha, 3 (1).
Yunus, Abidin (2015). Pembelajaran Multiliterasi Sebuah Jawaban atas Tantangan Pendidikan Abad Ke-21 dalam Konteks Keindoinesian (Bandung: Refika Aditama) 